Print version available at https://www.bloomsbury.com/uk/an-anthology-of-europeanneo-latin-literature-9781350157309/

P. Toribio, 'Newton on Theology', in G. Manuwald, D. Hadas and L. R. Nicholas (eds), An Anthology of European Neo-Latin Literature, London: Bloomsbury, 2020, 267-78.

\title{
Newton on Theology
}

\section{Isaac Newton (1642-1727), Theological Section from the General Scholium to the Principia Mathematica}

\author{
Pablo Toribio ${ }^{1}$
}

\section{Introduction}

Isaac Newton (1642-1727) is one of the greatest figures in the history of science. He made groundbreaking discoveries in physics and mathematics, including the law of universal gravitation, the laws of motion, the heterogeneity of white light, and the development of infinitesimal calculus. He was additionally deeply engaged with alchemy, both theoretical and practical. Moreover, Newton was devoted throughout his whole adult life to private study of the Bible (especially the Book of Revelation), the early history of the Christian Church, and the chronology of ancient nations. In the final three decades of his life he combined these intellectual endeavours with his position as guardian and then master of the Royal Mint as well as the presidency of the Royal Society.

As a young man, Newton was constantly exposed to Latin: first during his primary education at the Free Grammar School of Grantham (Westfall 1980: 55-7) and then at Trinity College, Cambridge, where students were supposed to 'speak Latin all the time they were in Hall' (Iliffe 2017: 74). Much of the scholarly literature Newton was reading and engaging with was written in Latin, and he consequently used it to a considerable extent in his own productions, particularly in the fields of natural philosophy, mathematics and church history. In his manuscript notes shifts are frequently found from English to Latin and vice versa, mostly depending on the sources being discussed. However, from the late 1690s onwards, when Newton entered the public sphere and moved to London, his overall Latin production decreased significantly.

Newton may have chosen to write in Latin his masterpiece, Philosophiae naturalis principia mathematica ('Mathematical principles of natural philosophy', 1687), not only owing to the status of the ancient language as scholarly lingua franca, but also because the work was in many regards intended as a response (Smith 2008) to René Descartes' Principia philosophiae ('Principles of philosophy', 1644). As for the choice of English for Newton's second major work, the Opticks (1704), reasons related to the contents have been suggested. For Grafton (1996: 206), 'even Sir Isaac Newton, who used his fluent Latin as the appropriate dress for the great baroque world picture of the Principia, used English for the pullulating experimental details of his Opticks'. 
Cohen (2001: 41) argued that this choice 'would seem to be a kind of admission by Newton of the imperfect or incomplete nature of the Opticks'. In any case the work was soon translated into Latin in an augmented edition under his own supervision (Optice, 1706).

For Newton writing was largely 'a question of finding the right words, and specifically of finding matter-of-fact, nonmetaphoric words' (Coetzee 1992: 187). His meticulousness in chosing his wording is certainly confirmed by the vast numbers of drafts that make up his vast manuscript legacy. ${ }^{2}$ This meticulousness, however, did not always militate against accidental mistakes: a phrase such as de origine schismatico (instead of schismatica, 'on the schismatic origin', see Toribio 2013: 129-30) or rei alicuius incorporei (instead of incorporeae, see n. 10 below) are striking but not utterly exceptional.

Although a systematic study on Newton's Latinity is still to be undertaken, some of its features are apparent, such as its remarkable lack of classical allusions: when classical literature is referred to, it serves no ornamental function, but is rather used as evidence for historical claims. Newton's writing displays a tendency towards concision and terseness that is very well exemplified in our selection. Here, his striking taste for asyndeton is perceivable, as is his sparse use of connectors, in spite of the complexity of his chain of thought. In relation to this, it is possible to observe the frequent occurrence of lists, parallelisms and tricolons, such as the beautifully worded one on God's inaccessibility to human senses (more minime humano, more minime corporeo, more nobis prorsus incognito).

The General Scholium included in the second (1713) and third (1726) editions of the Principia contains some of Newton's very rare public statements on theology. This brief but extremely rich piece brings together crucial aspects of Newton's natural philosophical and theological thought. The presentation of gravity in the Principia as a force acting at a distance, without any apparent mechanical cause, aroused serious criticisms from Gottfried Wilhelm Leibniz (see Text 18) and others: they considered that Newton was 'using the enormous cultural prestige of mathematics to reintroduce occult principles' (Shapin 1996: 63; see Snobelen 2001: 174). In the General Scholium Newton counterattacked with criticisms of both conventional mechanical philosophy and of philosophical conceptions identifying God with Nature.

The Scholium begins by describing how the movements of celestial bodies cannot be accounted for with Descartes's mechanical hypothesis. As Newton put it, it is not the task of a natural philosopher to 'invent' hypotheses in order to account for gravity (hypotheses non fingo ['I do not invent hypotheses'], he famously writes towards the end), but to deduce 'propositions' from phenomena and to make them general 'by induction'. This self-imposed methodological framework allows Newton to claim (at the end of this selection) that discussions about God do belong to natural philosophy, provided that they are based on the observation of natural phenomena. In keeping with this, the discussion about God is introduced by a typical enunciation of the argument of design (Shapin 1996: 142-8), according to which the perfect constitution of nature bears witness to the existence of a Creator. With the characterisation of God that follows, Newton makes it clear that he is by no means implying that nature is alive and endowed with occult qualities; on the contrary, Newton's God is the personal God of the Bible, who rules over his creation as an absolute monarch. In his further description of God, several lines of thought arising from Newton's decades-long research program on biblical exegesis and the history of the early Church and ancient religions converge.

Of particular interest are Newton's claims about the word 'God': for Newton this is a relative term, only definable by reference to the entities said to be subordinate 
to the one who is called 'god'. The implications of this reasoning are widely attested in Newton's theological manuscripts: there are true and false gods (depending on their ascendancy being true or false), and higher and lower gods. The highest God is by definition only one, and for Newton this is the God of the Bible, God the Father only. Christ is not the highest God: however, he is true God, in as much as the ascendancy which he has received from the Father is a true one. Orthodox Trinitarianism can therefore be legitimately seen as an implied, secondary target of the theological section of the General Scholium: in fact, it was occasionally read that way in the early eighteenth century (Snobelen 2005: 275-83).

\section{Notes}

1. I have written this section as a researcher of the ILC, CSIC (Madrid) and as a member of project FFI2017-86726-P, funded by the AEI / FEDER (European Union). I am grateful to William B. Barton for his careful revision of an earlier version of the introduction.

2. The draft material for the General Scholium is mostly held in Cambridge University Library (henceforward: CUL), in MS Add. 3965, and can be viewed online via the Cambridge Digital Library. For transcriptions and translations of many of Newton's manuscripts see the websites of The Newton Project, The Newton Project Canada and The Chymistry of Isaac Newton.

\section{Bibliography}

Casini, P. (1984), 'Newton: The Classical Scholia', History of Science, 22 (1): 1-58.

Coetzee, J. M. (1992), 'Isaac Newton and the Ideal of a Transparent Scientific Language (1982)', in D. Attwell (ed.), J. M. Coetzee: Doubling the Point. Essays and Interviews, 184-92, Cambridge MA.

Cohen, I. B. and A. Whitman (1999), Isaac Newton: The Principia: Mathematical Principles of Natural Philosophy. A New Translation. Preceded by a Guide to Newton's Principia by I. Bernard Cohen, Berkeley.

Cohen I. B. (2001), 'The Case of the Missing Author: The Title Page of Newton's Opticks (1704), with Notes on the Title Page of Huygen's Traité de la lumière', in I. B. Cohen and J. Z. Buchwald (eds), Isaac Newton's Natural Philosophy, 15-45, Cambridge MA.

Grafton, A. (1996), 'The New Science and the Traditions of Humanism', in J. Kraye (ed), The Cambridge Companion to Renaissance Humanism, 203-23, Cambridge.

Iliffe, R. (2017), Priest of Nature: The Religious Worlds of Isaac Newton, Oxford.

Koyré, A., I. B. Cohen and A. Whitman (1972), Isaac Newton's Philosophiae naturalis principia mathematica: 3rd ed. with Variant Readings, London.

Levitin, D. (2016), 'Newton and Scholastic Philosophy', British Journal for the History of Science, 49 (1): 53-77.

Motte, A. (1729), The Mathematical Principles of Natural Philosophy. By Isaac Newton. Translated into English by Andrew Motte, Vol. 2, London.

Pococke, E. (1650), Specimen historiae Arabum, sive Gregorii Abul Farajii Malatiensis de origine et moribus Arabum succincta narratio, Oxford.

Shapin, S. (1996), The Scientific Revolution, Chicago / London. 
Smith, G. (2008), 'Newton's Philosophiae Naturalis Principia Mathematica', in E. N. Zalta (ed.), The Stanford Encyclopedia of Philosophy (http://plato.stanford.edu/archives/win2008/entries/newton-principia/).

Snobelen, S. D. (2001), 'God of Gods, and Lord of Lords: The Theology of Isaac Newton's General Scholium to the Principia', Osiris, 16: 169-208.

Snobelen, S. D. (2005), 'Isaac Newton, Socinianism, and the One Supreme God', in M. Mulsow and J. Rohls (eds), Socinianism and Arminianism: Antitrinitarians, Calvinists and Cultural Exchange in Seventeenth-Century Europe, 241-98, Leiden.

Toribio, P. (2013), Isaac Newton: Historia ecclesiastica (de origine schismatico ecclesiae papisticae bicornis). Edición crítica, traducción y estudio, Madrid.

Westfall, R. (1980), Never at Rest: A Biography of Isaac Newton, Cambridge.

Whiston, W. (1728), Sir Isaac Newton's Corollaries from His Philosophy and Chronology, in His Own Words, London.

\section{Source of the Latin Text}

The text that follows is based on the third edition of the Principia (see facsimile with apparatus in Koyré, Cohen and Whitman 1972: 759-65). Punctuation has been standardized in places. Capitalization remains the same as in the original. Previous English translations include Whiston (1728: 6-10), Motte (1729: 388-92), and Cohen and Whitman (1999: 940-3).

\section{Latin Text}

... Elegantissima haecce solis, planetarum et cometarum compages non nisi consilio et dominio entis intelligentis et potentis oriri potuit. Et si stellae fixae sint centra similium systematum, haec omnia simili consilio constructa suberunt Unius dominio: praesertim cum lux fixarum sit eiusdem naturae ac lux solis, et systemata omnia lucem in omnia invicem immittant, et ne fixarum systemata per gravitatem suam in se mutuo cadant, hic eadem $<\mathrm{ad}>$ immensam ab invicem distantiam posuerit. ${ }^{1}$

Hic omnia regit non ut anima mundi, ${ }^{2}$ sed ut universorum dominus. Et propter

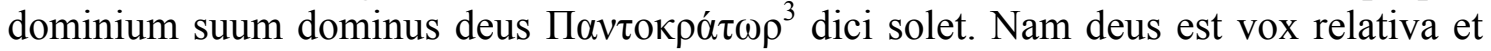
ad servos refertur: et deitas est dominatio dei, non in corpus proprium, uti sentiunt quibus deus est anima mundi, sed in servos. Deus summus est ens aeternum, infinitum, absolute perfectum: sed ens utcunque perfectum sine dominio non est dominus deus. Dicimus enim deus meus, deus vester, deus Israelis, deus deorum et dominus dominorum, sed non dicimus aeternus meus, aeternus vester, aeternus Israelis, aeternus deorum; non dicimus infinitus meus vel perfectus meus. Hae appellationes relationem non habent ad servos. Vox deus passim significat dominum, ${ }^{4}$ sed omnis dominus non est deus. Dominatio entis spiritualis deum constituit, vera verum, summa summum, ficta fictum. Et ex dominatione vera sequitur deum verum esse vivum, intelligentem et potentem; ex reliquis perfectionibus summum esse vel summe perfectum.

Aeternus est et infinitus, omnipotens et omnisciens, id est, durat ab aeterno in aeternum et adest ab infinito in infinitum; omnia regit et omnia cognoscit, quae fiunt aut fieri possunt. Non est aeternitas et infinitas, sed aeternus et infinitus; non est duratio et spatium, sed durat et adest. Durat semper et adest ubique, et existendo semper et ubique durationem et spatium constituit. Cum unaquaque spatii particula sit semper et unumquodque durationis indivisibile momentum ubique, certe rerum omnium fabricator 
ac dominus non erit nunquam, nusquam. Omnis anima sentiens diversis temporibus et in diversis sensuum et motuum organis eadem est persona indivisibilis. Partes dantur successivae in duratione, coexistentes in spatio, neutrae in persona hominis seu principio eius cogitante; et multo minus in substantia cogitante dei. ${ }^{5}$ Omnis homo, quatenus res sentiens, est unus et idem homo durante vita sua in omnibus et singulis sensuum organis. Deus est unus et idem deus semper et ubique. Omnipraesens est non per virtutem solam, sed etiam per substantiam: nam virtus sine substantia subsistere non potest. ${ }^{6}$ In ipso continentur ${ }^{7}$ et moventur universa, sed sine mutua passione. Deus nihil patitur ex corporum motibus, illa nullam sentiunt resistentiam ex omnipraesentia dei. ${ }^{8}$

Deum summum necessario existere in confesso est, et eadem necessitate semper est et ubique. Unde etiam totus est sui similis, totus oculus, totus auris, totus cerebrum, totus brachium, totus vis sentiendi, intelligendi et agendi, ${ }^{9}$ sed more minime humano, more minime corporeo, more nobis prorsus incognito. Ut caecus non habet ideam colorum, sic nos ideam non habemus modorum, quibus deus sapientissimus sentit et intelligit omnia. Corpore omni et figura corporea prorsus destituitur, ideoque videri non potest, nec audiri, nec tangi, nec sub specie rei alicuius corporeae ${ }^{10}$ coli debet. Ideas habemus attributorum eius, sed quid sit rei alicuius substantia minime cognoscimus. Videmus tantum corporum figuras et colores, audimus tantum sonos, tangimus tantum superficies externas, olfacimus odores solos et gustamus sapores: intimas substantias nullo sensu, nulla actione reflexa ${ }^{11}$ cognoscimus; et multo minus ideam habemus substantiae dei. Hunc cognoscimus solummodo per proprietates eius et attributa et per sapientissimas et optimas rerum structuras et causas finales, et admiramur ob perfectiones; veneramur autem et colimus ob dominium. Colimus enim ut servi, et deus sine dominio, providentia et causis finalibus nihil aliud est quam fatum et natura. A caeca necessitate metaphysica, quae utique eadem est semper et ubique, nulla oritur rerum variatio. Tota rerum conditarum pro locis ac temporibus diversitas ab ideis et voluntate entis necessario existentis solummodo oriri potuit. ${ }^{12}$

Dicitur autem deus per allegoriam videre, audire, loqui, ridere, amare, odio habere, cupere, dare, accipere, gaudere, irasci, pugnare, fabricare, condere, construere. Nam sermo omnis de deo a rebus humanis per similitudinem aliquam desumitur, non perfectam quidem, sed aliqualem tamen. Et haec de deo, de quo utique ex phaenomenis disserere ad philosophiam naturalem pertinet.

\section{English translation}

... This most elegant structure of the Sun, the planets and the comets could not have originated without the decision and dominion of an intelligent and powerful being. And if the fixed stars are the centres of similar systems, all these, built by a similar decision, will be subjected to the dominion of One: especially since the light of the fixed [stars] is of the same nature as the light of the Sun, and all systems exchange light with all others, and [since], in order to avoid systems of the fixed [stars] falling upon each other on account of their mutual gravity, He has placed them at an immense distance from each other. ${ }^{1}$

He governs all things not as the soul of the world, ${ }^{2}$ but as Lord of everything. And because of his dominion, the Lord God is usually called Pantokrator. ${ }^{3}$ For 'God' is a relative word and is used with reference to servants, and deity is God's domination not over his own body, as those for whom God is the soul of the world believe, but over servants. The highest God is an eternal, infinite, absolutely perfect being, but a being, however perfect, without dominion is not the Lord God. For we say 'my God', 'your 
God', 'God of Israel', 'God of gods' and 'Lord of lords', but we do not say 'my eternal', 'your eternal', 'eternal of Israel', 'eternal of gods'; we do not say 'my infinite' or 'my perfect'. These names have no relation to servants. The term 'God' means everywhere 'lord', but every lord is not a god. It is the domination of a spiritual being that makes a god: a true [domination makes] a true [god], the highest [domination makes] the highest [god], a false [domination makes] a false [god]. And from his true domination it follows that the true God is alive, intelligent and powerful; from his other perfect qualities it follows that he is the highest, or perfect in the highest way.

$\mathrm{He}$ is eternal and infinite, almighty and all-knowing, that is, he lasts from everlasting to everlasting, and is present from infinity to infinity; he governs all things and knows all things that happen or can happen. He is not eternity and infinity, but eternal and infinite; he is not duration and space, but lasts and is present. He lasts forever and is present everywhere, and by existing always and everywhere he establishes duration and space. Since each particle of space exists always and each indivisible moment of duration exists everywhere, the maker and lord of all things will certainly not exist at no time, nowhere. Every perceiving soul is the same indivisible person through different times and in the different instruments of its senses and movements. There are successive parts in duration, coexisting [parts] in space, [but] neither [of these sorts of] parts is in the person of a human being or in its thinking principle; and much less [are there parts] in the thinking substance ${ }^{5}$ of God. Every human being, insofar as it is a perceiving thing, is one and the same human being during its whole life in each and every instrument of its senses. God is one and the same God always and everywhere. He is omnipresent not only through his power, but also through his substance, since power cannot subsist without substance. ${ }^{6}$ In him everything is contained $^{7}$ and moves itself, but without their mutually affecting each other. God is not affected in any way by the movements of bodies, [and] these do not experience any resistance from God's omnipresence. ${ }^{8}$

It is acknowledged that the highest God necessarily exists, and by the same necessity he is always and everywhere. Therefore he is also all similar to himself: all eye, all ear, all brain, all arm, all ability to perceive, to understand and to act, ${ }^{9}$ but in a manner in no way human, in a manner in no way corporeal, in a manner completely unknown to us. As a blind person does not have any idea of the colours, so we do not have any idea of the ways in which the most wise God perceives and understands everything. He lacks any body or corporeal shape whatsoever, and therefore he cannot be seen, or heard, or touched, nor should he be worshipped under the form of any corporeal thing. ${ }^{10}$ We have ideas of his attributes, but we do not know at all what the substance of any thing is. We see only shapes and colours of bodies; we hear only sounds; we touch only external surfaces; we smell only odours and taste only flavours: by no sense, by no reflection ${ }^{11}$ do we know the inner substances, and much less do we have any idea of God's substance. We know him only through his properties and attributes, as well as through the most wise and excellent constructions and final causes of things, and we admire [him] on account of his perfect qualities; but we venerate and worship [him] on account of his dominion. Indeed, we worship [him] as servants, and a god without dominion, providence and final causes is nothing but fate and nature. From a blind metaphysical necessity, which is certainly the same always and everywhere, no variation of things originates. The whole diversity of created things in different places and times could only originate from the ideas and will of a necessarily existing being. ${ }^{12}$

On the other hand, God is allegorically said to see, to hear, to speak, to laugh, to love, to hate, to desire, to give, to receive, to feel joy, to get angry, to fight, to produce, to establish, to build, since all language about God is taken from human realities by way 
of a certain similarity, no doubt imperfect, but still of some kind. And [I will say] that much about God - to discuss him from phenomena certainly does belong to natural philosophy.

\section{Commentary}

1. et ne fixarum... posuerit] The whole phrase was inserted in the 1726 edition after a full stop. The misleading punctuation in the original has caused all previous English translations to render the clause as an independent item, in spite of the fact that, as implied by the subjunctive posuerit, cum ('since') still applies. The omission of ad with the resulting loose double accusative construction is also most probably accidental, as suggested by some of Newton's drafts (see CUL, MS Add. 3965, fol. 468v). Elsewhere Newton took Lucretius, De rerum natura 5.91-109 as evidence that the possibility of different star systems falling upon each other on account of their gravity was a genuinely held fear in the ancient world (Casini 1984: 27-8).

2. The reference is to the widespread Platonic doctrine of the 'soul of the world', according to which the world is a living being endowed with soul and intelligence (Plato, Timaeus 30bc). See further n. 7.

3. Newton's note a: 'Id est Imperator universalis.' ('That is, "universal emperor"').

4. Newton's note b: 'Pocockus noster vocem dei deducit a voce Arabica du, et in casu obliquo di, quae dominum significat. Et hoc sensu principes vocantur dii: Psalm. LXXXII, 6 et Ioan. X, 35. Et Moses dicitur deus fratris Aaron et deus regis Pharaoh (Exod. IV, 16 et VII, 1). Et eodem sensu animae principum mortuorum olim a gentibus vocabantur dii, sed falso propter defectum dominii.' ('Our Pococke derives the term deus from the Arabic term $d u$ (and in the oblique case di), which means "lord". And in this sense princes are called gods: Psalm LXXXII, 6 and John X, 35. And Moses is called god of his brother Aaron and god of the King Pharaoh (Exodus IV, 16 and VII, 1). And in the same sense the souls of dead princes were called gods by the Gentiles in ancient times, but falsely, due to their lack of dominion.') Newton refers to the celebrated Oxford Orientalist Edward Pococke (1604-91), who does discuss the Arabic term du as meaning 'lord' (Pococke 1650: 104), but does not establish any connection between this term and the Latin deus. The biblical passages listed next refer to cases where people other than God are called gods: Moses in Exodus, the 'mighty' (princes and judges) in Psalm 82 (Vulgate 81):6; the latter is quoted in John 10:35. These two references are erroneously rendered as Psalm 84 and John 10:45 in the original.

5. substantia cogitans or 'thinking substance' is a typically Cartesian phrase referring to personal identity. Newton draws a parallel between God's 'thinking substance' and the human 'thinking principle', which Newton gives as a synonym for persona. The correspondence implies that God is also a single 'person', thereby contradicting the doctrine of the Trinity, which postulates a single substance and three persons. If the printed wording is at odds with Trinitarian orthodoxy, there is manuscript evidence that Newton even envisaged a much bolder version: et multo minus in persona Dei, 'and much less in the person of God' (CUL, Add. Ms. 3965, fol. 539r). 
6. As shown by Levitin (2016: 70-3), this is a commonplace attack on the concept of 'virtual extension', which scholastic philosophers had applied to souls and other incorporeal entities. For anti-scholastic philosophers like Newton, the possibility of something being only virtually extended was nonsensical.

7. Newton's note c: 'Ita sentiebant veteres, ut Pythagoras apud Ciceronem, de Natura deorum, lib. I; Thales; Anaxagoras; Virgilius, Georgic. lib. IV, v. 220 et Aeneid. lib. VI, v. 721; Philo, Allegor. lib. I sub initio; Aratus in Phaenom. sub initio. Ita etiam scriptores sacri ut Paulus in Act. XVII, 27, 28; Iohannes in Evang. XIV, 2; Moses in Deut. IV, 39 et X, 14; David, Psal. CXXXIX, 7, 8, 9; Salomon, I Reg. VIII, 27; Iob, XXII, 12, 13, 14; Ieremias XXIII, 23, 24. Fingebant autem idololatrae solem, lunam et astra, animas hominum et alias mundi partes esse partes dei summi et ideo colendas, sed falso.' ('The ancients believed this, as Pythagoras in Cicero, On the nature of the gods, book I; Thales; Anaxagoras; Virgil, Georgics, book IV, v. 220 and Aeneid, book VI, v. 721; Philo, Allegories, book I, at the beginning; Aratus, Phaenomena, at the beginning. So also the sacred writers, such as Paul in Acts, XVII, 27, 28; John in his Gospel, XIV, 2; Moses in Deuteronomy, IV, 29 and X, 14; David, Psalm CXXXIX, 7, 8, 9; Salomon, I Kings VIII, 17; Job, XXII, 12, 13, 14; Jeremiah, XXIII, 23, 24. Moreover, idolaters imagined that the Sun, the Moon and the stars, the souls of people and other parts of the world were parts of the highest God and therefore to be worshipped, but [this was] false.'). The classical references here include passages where the world is presented as a living, divine being (according to the doctrine of the anima mundi ['soul of the world'], idolatrous in Newton's eyes). The Apostle Paul's famous reference to Aratus in Acts 17:28 works as a bridge between the classical references and the biblical ones. The latter depict God as exceeding the dimensions of heaven and earth (1 Kings 8:27), and at the same time being present everywhere (Psalm 139 [Vulgate 138]:7). The last sentence insists again on ancient idolatry conflating God and his creation.

8. Of course, this does not mean that physical bodies are not affected by God's will, but by the incorporeal quality of His omnipresence.

9. Newton is here probably echoing his own reading of the second-century heresiologist Irenaeus of Lyon (Against the heresies 2, 13, 3): 'He is simple \& not compound. He is all \& equal to himself, all sense, all spirit, all perception, all Ennoea, all $\lambda o ́ \gamma o \varsigma$ [logos, 'word'], all ear, all eye, all light. He is all sense which cannot be separated from itself, nor is there anything in him which can be emitted from anything else. Thus does Irenaeus represent \& confute the Metaphysicks of the Gnosticks.' (Newton's drafts in Jerusalem, National Library of Israel, Yahuda Ms. 15.7, fol. 128r).

10. The original reads sub specie rei alicuius corporei, as if the feminine noun res were masculine or neuter. Translators have implicitly corrected corporei into corporeae: 'under the representation of any corporeal thing' (Whiston 1728:9; Motte 1729: 391), 'in the form of something corporeal' (Cohen and Whitman 1999:942). The correction also appears in editions of the Latin text following Newton's death.

11. actio reflexa usually means 'reflex act' (as in Descartes: see Shapin 1996: 48-9). Here Newton must have intended the meaning of the scholastic phrase actus reflexus: 'reflection' based on perceptions through the senses.

12. This reuses the argument of intelligent design, stated at the beginning of this section, against atheism. The previous sentence (A caeca necessitate 
metaphysica...) also implies opposition to any philosophy equating God to his creation. For Newton, the only truly Christian philosophy of nature is the one allegedly resulting from his world view: one that confirms God's intelligent control over nature as a separate entity. 